\title{
Dolphin software accuracy in soft tissue facial profile prediction of Class II patients in orthognathic surgery
}

\author{
Precisão de software Dolphin na predição do perfil facial de tecidos \\ moles de pacientes Classe II submetidos a cirurgia ortognática
}

\author{
Claudio Roberto Pacheco JODAS ${ }^{\text {ID }}$ https://orcid.org/0000-0002-9750-2714 \\ Rubens Gonçalves TEIXEIRA ${ }^{1}$ iD https://orcid.org/0000-0003-0814-0940 \\ Marilia de Oliveira Coelho Dutra LEAL² iD https://orcid.org/0000-0003-1164-9983 \\ Sarah Teixeira COSTA3 iD https://orcid.org/0000-0001-5417-9112 \\ Wanderley ZANFORLIN JUNIOR ${ }^{1}$ iD https://orcid.org/0000-0002-1741-4723 \\ Paulo Roberto Aranha NOUER ${ }^{4}$ iD https://orcid.org/0000-0003-3239-4780
}

\section{ABSTRACT}

Objective: The present study aimed to analyze the accuracy of the Dolphin Imaging $11.9^{\circledR}$ computer program in the surgical prediction of the soft tissue facial profile. Methods: The investigators designed and implemented a retrospective study. It was used a sample of 55 patients, being 14 males and 41 females, aged from 19 to 55 years old. All patients were subjected to surgery orthognathic bimaxillary combined with mentoplasty, in Class II facial profile - Angle. Patients' actual results were compared to the obtained up to a year and a half after the surgery procedure. The study was delineated in three phases. In the first phase, cephalometric preoperative radiographs were performed; in the second phase the postoperative cephalometries were made; in the third phase, the measurements of the soft profile of the virtual analysis were compared with the real post-surgical profile. The data was collected and subjected to statistical analysis in the "R" program, using the t test and ANOVA. Results: The results demonstrated that measures $A^{\prime}$ and Eis were underestimated in $-0.15 \pm 0.52 \mathrm{~mm}$ and $-0.47 \pm 1.05 \mathrm{~mm}$, respectively, while measures $\mathrm{Pg}^{\prime}$ and $\mathrm{ANL}$ were overestimated at $0.76 \pm 1.98 \mathrm{~mm}$ and $3.31 \pm 3.60^{\circ}$ respectively. There was no evidence of measures, Ls, Li and B', being different between real and virtual. Conclusion: The results of this study suggest that Dolphin $11.9^{\circledR}$ computer program complies with the function of preserving with reliability virtual surgical planning.

Indexing terms: Malocclusion. Malocclusion, Angle class II. Orthodontics. Orthognathic surgery.

\section{RESUMO}

Objetivo: O presente estudo teve como objetivo analisar a precisão do programa de computador Dolphin Imaging $11.9^{\circledR}$ na predição cirúrgica do perfil facial dos tecidos moles. Métodos: Os pesquisadores projetaram e implementaram um estudo retrospectivo.

$\boldsymbol{\nabla} \boldsymbol{\nabla} \boldsymbol{\nabla}$

1 Faculdade São Leopoldo Mandic, Instituto de Pesquisas São Leopoldo Mandic, Departamento de Cirurgias Bucomaxilofaciais. Rua Dr. José Rocha Junqueira, 13, 13045-755, Ponte Preta, Campinas, SP, Brasil.

2 Universidade Estadual de Campinas, Faculdade de Odontologia de Piracicaba, Departamento de Patologia. Piracicaba, SP, Brasil.

${ }^{3}$ Centro Universitário Presidente Tancredo de Almeida Neves, Faculdade/Departamento de Odontologia. Av. Dr. José Caetano de Carvalho, 751, Centro, 36307-251, São João del Rei, MG, Brasil. Correspondence to: ST COSTA. E-mail: <sarahteixeiracosta@yahoo.com.br>.

${ }^{4}$ Faculdade São Leopoldo Mandic, Instituto de Pesquisas São Leopoldo Mandic, Departamento de Ortodontia. Campinas, SP, Brasil.

$\boldsymbol{\nabla} \mathbf{v} \boldsymbol{\nabla}$

How to cite this article

Jodas CRP, Teixeira RG, Leal MOCD, Costa ST, Zanforlin Junior W, Nouer PRA. Dolphin software accuracy in soft tissue facial profile prediction of Class II patients in orthognathic surgery. RGO, Rev Gaúch Odontol. 2021;69:e20210051. http://dx.doi.org/10.1590/1981863720210005120200076 
Utilizou-se uma amostra de 55 pacientes, sendo 14 do sexo masculino e 41 do sexo feminino, com idades entre 19 e 55 anos. Todos os pacientes foram submetidos à cirurgia ortognática bimaxilar combinada com mentoplastia, no perfil facial Classe II de Angle. Os resultados reais dos pacientes foram comparados com os obtidos até um ano e meio após o procedimento cirúrgico. O estudo foi delineado em três fases. Na primeira fase, foram realizadas radiografias cefalométricas pré-operatórias; na segunda fase, foram realizadas cefalometrias pós-operatórias; na terceira fase, as medidas do perfil mole da análise virtual foram comparadas com o perfil pós-cirúrgico real. Os dados foram coletados e submetidos à análise estatística no programa " $R$ ", utilizando o teste $t$ e ANOVA. Resultados: Os resultados demonstraram que as medidas $A$ 'e Eis foram subestimadas em -0,15 $\pm 0,52 \mathrm{~mm}$ e $-0,47 \pm 1,05 \mathrm{~mm}$, respectivamente; enquanto as medidas $P g^{\prime}$ e ANL foram superestimadas em 0,76 $1,98 \mathrm{~mm}$ e 3,31 $\pm 3,60^{\circ}$, respectivamente. Não houve evidência de medidas, $L S$, Li e $B^{\prime}$, sendo diferentes entre real e virtual. Conclusão: Os resultados deste estudo sugerem que o programa de computador Dolphin $11.9^{\circledR}$ cumpre a função de preservar com confiabilidade o planejamento cirúrgico virtual.

Termos de indexação: Má oclusão. Má oclusão classe /l de Angle. Ortodontia. Cirurgia ortognática.

\section{INTRODUCTION}

Currently, due to the great appreciation of facial harmony, the search for a better prediction of surgical outcomes has resulted in the development of new diagnostic instruments, such as facial analysis. These latest researches are consolidated on the established techniques of plaster modeling and cephalometric studies. Recently, the soft tissue thinking model, which directs the treatment of skeletal problems, emerged in orthodontics and orthognathic surgery. In the planning phase, skeletal tissue reference frames are used to determine changes necessary to provide a suitable soft tissue profile [1]. Hereupon, the postoperative facial profile results have made predictions more precise after the introduction of computer programs that have increased the precision of diagnosis and surgical results.

The use of computer programs is seasonable to perform virtual planning and explanation for patients who will undergo orthognathic surgery $[2,3]$. The Dolphin Imaging ${ }^{\circledR}$ (Dolphin Imaging \& Management Solutions, Chatsworth CA, USA) computer program has become the elective option for several surgeons due to its constant updates, strong presence in the current market and the quality of surgical prediction [4]. For these reasons, we selected this program for the current research as well.

Other authors have compared facial profile changes in patients with facial asymmetry with: Class II and III, only Class III, only Class II facial patterns, and bimaxillary surgery with maxillary segmentation. On the other hand, all these studies were applied on non-Brazilian subjects, therefore, there is no report on the degree of precision of the virtual planning for bimaxillary surgery combined with mentoplasty of patients with a Class II profile in a Brazilian sample. Brazilians are known as one of the most miscegenated population, bringing different patterns to facial profile. Over centuries our population mixed white, black, Asian, and native populations. Miscegenated population presents a unique spectrum of measurements, being very specific for these group population $[5,6]$.

Thus, the objective of this work is to analyze accuracy of the Dolphin $® 11.9$ computer program in the prediction of the soft tissue profile in Brazilian Class II patients submitted to bimaxillary orthognathic surgery combined with mentoplasty.

\section{METHODS}

This study followed the Declaration of Helsinki on medical protocol and ethics and the regional Ethical Review Board of São Leopoldo Mandic Research Ethics Committee, Protocol number 1.468.895/2016 approved this study. Participants provided informed written consent. The TRIPOD statement was used in this research.

The sample of the present study consisted of 552 records of Class II soft tissue profile patients submitted to bimaxillary orthognathic surgery with mentoplasty from January 2011 to December 2016 with at least 18 months of follow-up and whose data were archived in the Dolphin Imaging \& Management Solutions $11.9 \circledR$ program (Dolphin Imaging \& Management Solutions, Chatsworth (A, USA).

The inclusion criteria of the sample in the preoperative phase were adult patients with white ancestry, with full bone growth (18 years), without mutilation in the dental arches, with a minimum presence of 24 teeth in the dental arches, and with a Class II malocclusion skeletal pattern. After the surgical procedure, patients were selected for upper $\mathrm{V}$-Y suture $(2 \mathrm{~cm})$; final postoperative occlusion in a bilateral Class I occlusion; a postoperative period of at least 12 to 18 months of orthognathic surgery without signs of relapse and presenting good evolution; 


\section{Medical Records}

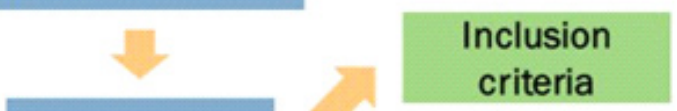

552 pacients

55 pacients

\section{$19-55$ years}

\section{1 females}

Figure 1. Fluxogram.

pre- and postoperative (digitized) cephalograms (lateral norm) with adequate quality and contrast, without distortion between them and clear visualization of anatomical points considered.

Exclusion criteria were the presence of pathologies, anomalies and/or previous traumatic events; the presence of extensive prosthetic rehabilitation or prosthetic spaces; or incomplete radiological documentation and insufficient data.

After applying the inclusion and exclusion criteria, the final sample consisted of 55 individuals, of whom 14 were male and 41 were female, and their ages ranged from 19 to 55 years old (figure 1).

All the lateral cephalometric radiographs were performed using Sorax X-ray digital image apparatus - Cranex D-XMind ${ }^{\circledR}$, kvp max 81, mA max 10, kW 1.8 (Tuusula, Finland). Materials for data collection were performed on Dolphin Imaging \& Management Solutions ${ }^{\circledR}$ software - version 11.9 (Canoga Park, California, 2009); and a Sony Vaio ${ }^{\circledR}$ computer with 32-bit Intel Core 2Duo T7250 2 Ghz, 2 GB of RAM memory and 500 GB of Hard Drive Disc (São Paulo, Brazil).

The study was delineated into three cephalometric measurement phases made by one researcher. In the first phase, cephalometric analysis was performed on lateral cephalometric radiographs based on virtually planned (preoperative) surgical predictions; in the second phase, cephalometric analysis was performed on postoperative lateral cephalograms. Finally, in the third phase, cephalometric analysis from the acquisition of two cephalometric evaluations of phases 1 and 2 were compared. Measurements of the soft profile in virtual

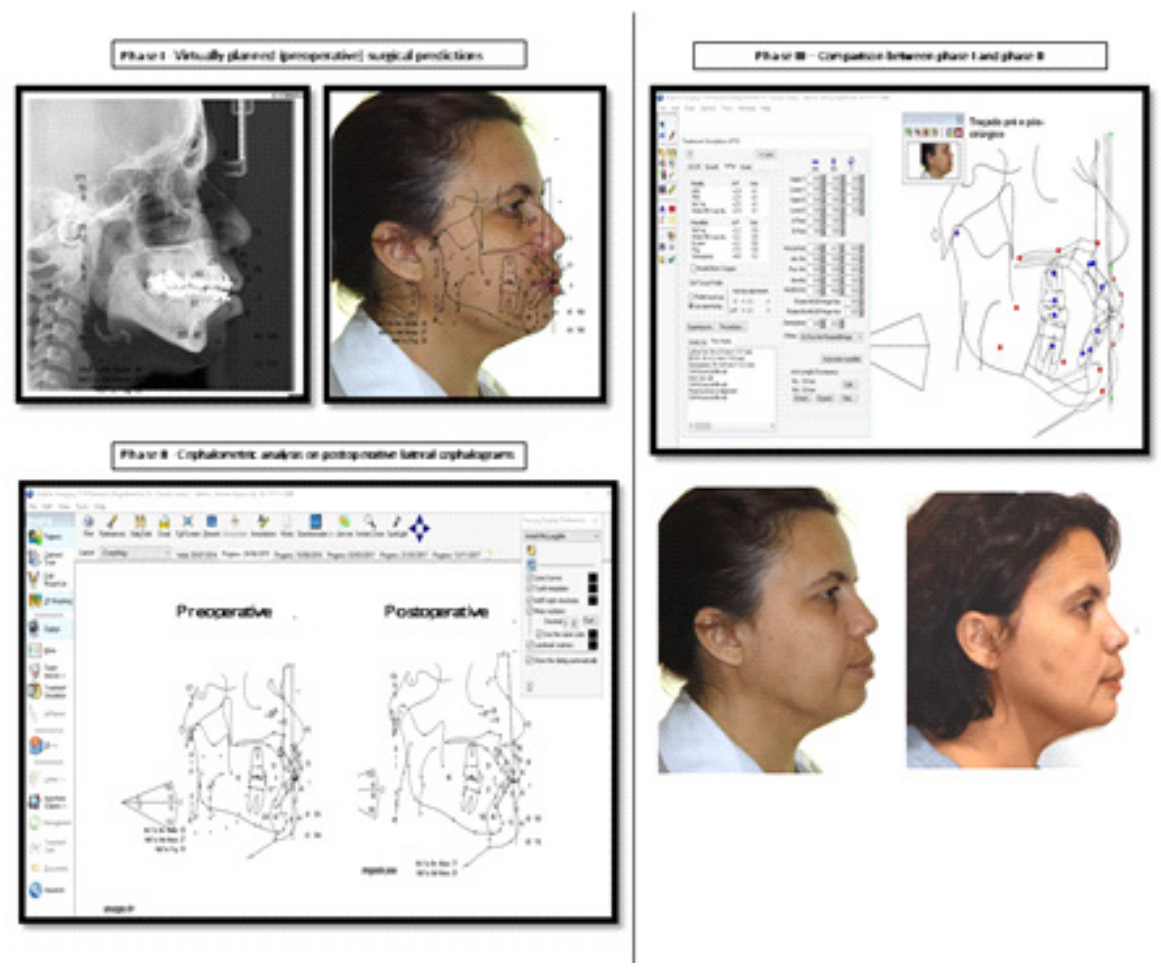

Figure 2. Cephalometric measurement phases. 
analysis (phase 1) were compared with those real profile after a period of 12 to 18 months (phase 2). The true vertical line (TVL) was the reference line for the comparison of points, defined as a straight line drawn between a horizontal point $8 \mathrm{~mm}$ previously projected to the glabella soft tissue and the subnasal soft tissue, extending until the submandibular region. The points were scored in the Dolphin $11.9^{\circledR}$ program twice by one professional: first before surgery to obtain virtual surgical planning and second within a period of 12 to 18 months after surgery (figure 2).

The points used for markings were the soft tissue A-point $\left(A^{\prime}\right)$, soft tissue $B$-point $\left(B^{\prime}\right)$, soft tissue pogonion

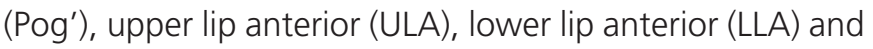
upper incisor exposure (ULI). The angle used for analysis was the nasolabial angle (NLA).

Measures performed for analyze real and virtual data were the distance from $A^{\prime}$ to $\operatorname{TVL}\left(A^{\prime} r\right)$ or $\left(A^{\prime} v\right)$, distance from $B^{\prime}$ to $T V L\left(B^{\prime} r\right)$ or $\left(B^{\prime} v\right)$, distance from Pog' to TVL (Pog'r) or (Pog'v), distance from ULA to TVL (ULAr) or (ULAv), distance from LLA to TVL (LLAr) or (LLAv), distance from ULI to TVL (ULIr) or (ULIV) and NLA real (NLAr) or NLA virtual (NLAv). All these measures and angles are used in Arnett's cephalometric analysis $[7,8]$, and these data were archived in a spreadsheet in Excel 7.0 ${ }^{\circledR}$.

Inferential statistics were performed to initially check the homogeneity of variances by Levene's test and the normality of distribution by the Kolmogorov-Smirnov test. Since variances were homogeneous and adhered to a normal distribution, the t-test for paired samples was used to verify the existence of differences between points in lateral cephalometric radiographs for surgical prediction and in postoperative lateral cephalometric radiographs. Data collected were recorded in a database prepared in Microsoft Office Excel ${ }^{\circledR}$ version 7.0 (Microsoft Corporation, USA) and statistical analysis was performed in " $R$ " version 3.4. A significance level a of $5 \%$ was used for all statistical tests $(p=0.05)$.

\section{RESULTS}

\section{Concordance analysis}

In order to calculate random estimator error and requires repetitions in at least $10 \%$ of the sample, the Dahlberg formula was used.
For the NLA variable, concordance analysis was satisfactory, with T values lower than 0.05 . As the T statistic of each repetition was smaller than the level of significance, there is evidence that the evaluator has a maximum $5 \%$ probability of rejecting the hypothesis as not accurate and therefore providing reliable measures of the ANL variable for further analyses.

In the variables $A^{\prime}$, ULA, ULI, LLA, B' and Pog', the occurrence of identical values was observed in the first and second repetitions; therefore, it draws the conclusion that there was absolute agreement in some patients. The intraclass correlation coefficient for continuous variables was obtained through program $\mathrm{R}$ version 3.4 .0 with the irr library, adopting the level of significance of 0.05 .

Analysis of coefficients revealed that ULA, LLA and NLA presented the optimum examiner reliability; the variables ULI, B' and Pog' exhibited absolute agreement given that several observations were identical between the first and second observations. Variable $A^{\prime}$ presented optimal agreement. However, it was considered only good due its confidence limit being under the threshold.

\section{Descriptive statistical analysis}

The sample consisted of measurements of 55 individuals of both sexes, from 19 to 55 years old, obtained first from lateral cephalometric radiographs before surgery and second from lateral cephalometric radiographs 12 to 18 months after surgery. Distances and angles by sex are shown in table 1.

\section{Inferential statistical analysis}

\section{Analysis of two-factor variance}

The ANOVA variance analysis model evaluated differences between sex and age in the real and virtual measurements. The mean difference of each pair of variables was used by convention. Seven variables were evaluated individually, with sex (female and male) and age group at 10-year intervals (up to the age of thirty years old, from the age of thirty to forty years old and above the age of forty years old inclusive) as factors in all models of each variable with the inclusion of a first-order interaction effect. 
Table 1. Distances and angles of each variable according to sex.

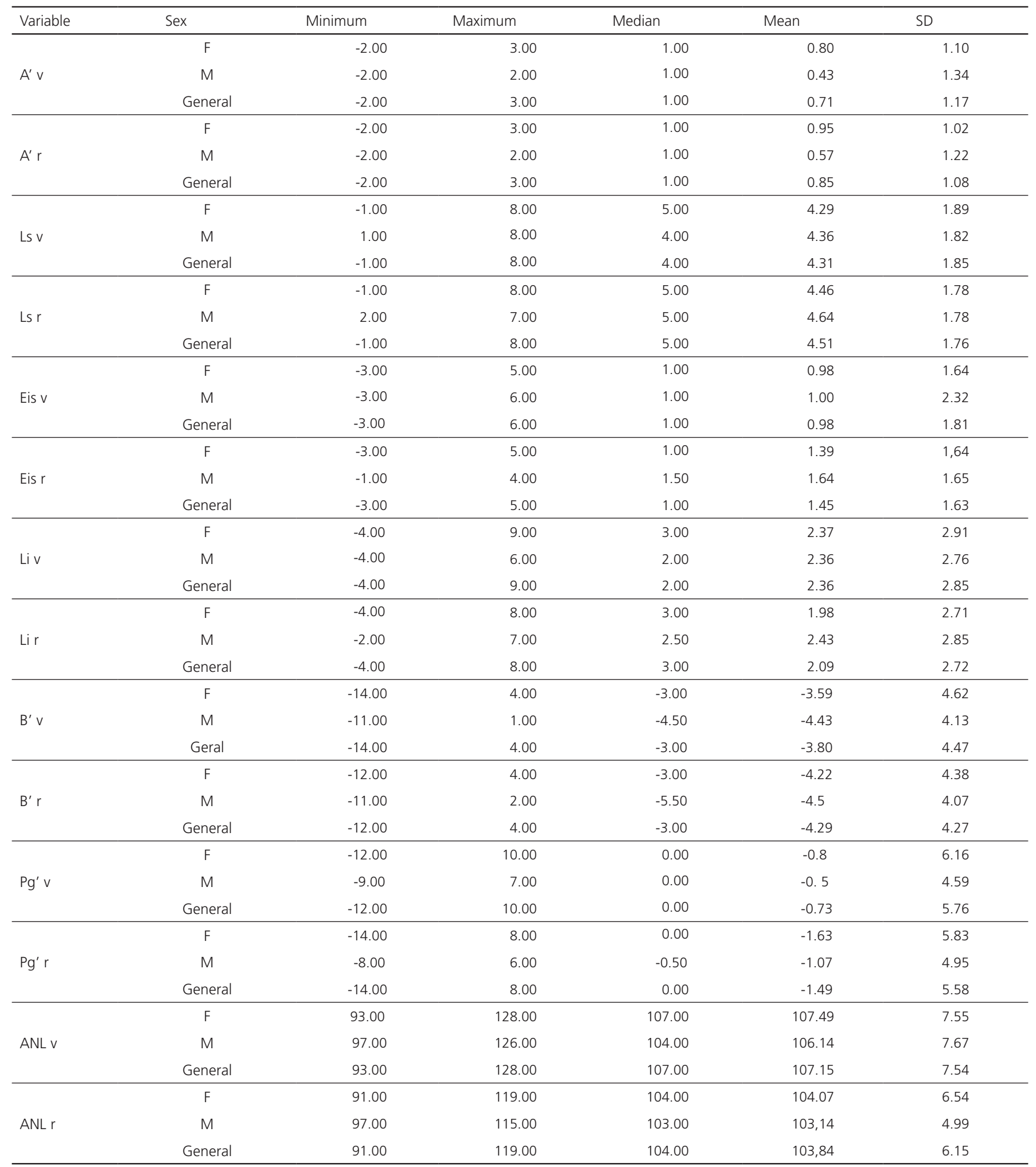

It was not found in any model an interaction or additive effect for the variables sex and age group; therefore, a paired Student's t test was used to compare actual measurements with virtual measurements.

\section{Paired t test}

Table 2 shows results of $t$ test applications for each variable. 
Table 2. Test t applications for each variable.

\begin{tabular}{|c|c|c|c|c|}
\hline Variable & $P$ value two-tailed & Meaning & $P$ value one tailed & Meaning \\
\hline$A^{\prime}$ & 0.044 & diferent & 0.022 & Virtual $<$ Real \\
\hline LS & 0.078 & equal & - & - \\
\hline Li & 0.164 & equal & - & - \\
\hline$B^{\prime}$ & 0.056 & equal & - & - \\
\hline
\end{tabular}

The $A^{\prime}$ and ULI measurements were underestimated in virtual planning at $-0.15 \pm 0.52 \mathrm{~mm}$ and $-0.47 \pm 1.05$ $\mathrm{mm}$, respectively, while the Pog' measurement and NLA were overestimated by $0.76 \pm 1.98 \mathrm{~mm}$ and $3.31^{\circ} \pm 3.60^{\circ}$, respectively. There was no evidence of differences in ULA, LLA and $\mathrm{B}^{\prime}$ between real and virtual measurements.

\section{DISCUSSION}

Increasing numbers of treatment plans for orthognathic surgery cases have been made by specific computer programs for this purpose. However, soft tissue changes are not well controlled and need to be better predicted for safety and assertiveness in the diagnosis and treatment plan process. Several programs have been evaluated in the literature, including the Dentofacial Planner Plus $^{\circledR}$, Quick Ceph Image ${ }^{\circledR}$, Portrait Planner ${ }^{\circledR}$, Nemoceph $^{\circledR}$, Maxilin ${ }^{\circledR}, \mathrm{KD}-\mathrm{MMS}^{\circledR}$ and Dolphin Imaging ${ }^{\circledR}$. These one, also analyzed by the present study, was the most widespread in research [2,9-11]. Updates are carried out regularly in this software, and version 11.9 (2017) was used in this study. However, as most software systems are based on indexes derived from studies in North American White individuals, the accuracy of prediction for different ethnicities becomes questionable [4]. The present sample contains Brazilian individuals, whom self-reported as white. However, these self-reported white individuals differ from the Caucasians (North American whites) used as samples for the database in which the program was developed.

In addition, the relationship between changes in hard and soft tissues can be very complex because of the different soft tissue morphologies and thicknesses combined with changes in weight, posture, elasticity, and/or tonicity, which may vary from person to person [1]. Predictive soft tissue surgical results are an integral part of the orthognathic surgery treatment plan. The greatest inaccuracies between the Dolphin ${ }^{\circledR}$ predictions and reality are found in the upper lip [10-12]. In the results of the present study, ULA did not present a statistically significant difference between what was planned and the actual result. The predicted ULA measurement in the Dolphin ${ }^{\circledR}$ program was found more in the posterior portion than its actual position [2]. The virtually planned Pog' was found higher than the real value; thus, it was considered as an overestimated measurement. All subjects were submitted to the mentoplasty procedure, which results in the advancement of the chin, that is, chin projection, and consequently a higher value of Pog'. It has been suggested that mentoplasty has an effect of protruding the soft pogonion and decreasing the mentolabial angle [1].

The LLA refers to the most anterior point of lower lip and composes a minor portion of the lower third of the face. There was no statistically significant difference between virtual planning and the actual results for the present study sample.

The predicted NLA was underestimated in virtual planning when compared to the real value. The mean error for NLA was $8^{\circ}$ [13]. The magnitude of clinical significance for angular measurements has not yet been well defined in the literature; however, the authors believe that $8^{\circ}$ is a clinically important error since the difference between NLA from $90^{\circ}$ to close to $100^{\circ}$ is apparently routine in clinical practice. The present study found values of NLA varying from $3.31^{\circ}+3.60^{\circ}$, representing a convergent value with the present literature.

In the vertical plane of $A^{\prime}$, Pog' $^{\prime}$ and $B^{\prime}$ there was no statistically significant difference between the predicted and actual results [2]. In the other hand, the present study showed a significant difference between virtual planning and the surgical outcome, with virtual values being underestimated for $A^{\prime}$ and overestimated for Pog'. Meanwhile, $\mathrm{B}^{\prime}$ corroborated with the authors showing no difference between real and virtual values. It is noteworthy that during the surgical procedure, all patients received 
type VY suture. This interferes with the variables $A^{\prime}$ and NLA because this type of suture tends to carry soft tissues anteriorly, thus projecting the upper lip forward and consequently making NLA sharper and decreasing the A'r distance.

The ULI corresponds to a distance from the incisal of the central incisor superior to the lower edge of the upper lip at rest and therefore refers to two points. Although there are no concise reports on distance, it is possible to infer that orthodontic movement for the finalization of treatment after orthognathic surgery directly influences the inclination of the upper anterior teeth. Therefore, this postsurgical orthodontic movement is not included in virtual predictions. In addition, such assumptions may make virtual prediction values smaller than the actual results.

Analysis of the soft profile is concentrated in the lower third of the face, where changes are not always proportional to the displacement of bone segments but instead, they are the result of complex interactions between different planes of soft tissue and their response to the retreat or advancement of hard tissue.

\section{CONCLUSION}

The Dolphin Imaging $11.9^{\circledR}$ computer program reliably predicted the virtual surgical planning proposed by the surgeon for the sample studied. The degree of accuracy was satisfactory; however, it showed different behaviors for the measurements analyzed. Virtual measures of $A^{\prime}$ and ULI were smaller than the real measures; meaning that they were underestimated. Virtual measures of Pog' and NLA were greater than the real measures; overestimated measurements/results. The virtual measurements of ULA, LLA and $B^{\prime}$ were not found different from the actual measurements.

\section{Collaborators}

CRP JODAS, conception and design of study, acquisition of data: laboratory or clinical/literature search, analysis and interpretation of data collected, drafting of article and/or critical revision, final approval and guarantor of manuscript. RG TEIXEIRA and W ZANFORLIN JUNIOR, analysis and interpretation of data collected, drafting of article and/or critical revision. MOCD LEAL and ST COSTA, acquisition of data: laboratory or clinical/literature search, analysis and interpretation of data collected, drafting of article and/or critical revision. PRA NOUER, Conception and design of study, Analysis and interpretation of data collected, Final approval and guarantor of manuscript.

\section{REFERENCES}

1. Joss CU, Joss-Vassalli IM, Kiliaridis S, Kuijpers-Jagtman AM. Soft tissue profile changes after bilateral sagittal split osteotomy for mandibular advancement: a systematic review. J Oral Maxillofac Surg. 2010;68(6):1260-1269. https://dx.doi. org/10.1016/j.joms.2010.01.005

2. Akhoundi MSA, Shirani G, Arshad M, Heidar H, Sodagar A. Comparison of an imaging software and manual prediction of soft tissue changes after orthognathic surgery. J Dent (Tehran). 2012;9(3):178-187.

3. Zhang SX, Heng PA, Liu ZJ, et al. The Chinese Visible Human $(\mathrm{CVH})$ datasets incorporate technical and imaging advances on earlier digital humans. J Anat. 2004;204(3):165-173. https://dx.doi.org/10.1111/j.0021-8782.2004.00274.x

4. Nadjmi N, Defrancq E, Mollemans W, Van Hemelen G, Bergé S. Quantitative validation of a computer-aided maxillofacial planning system, focusing on soft tissue deformations. Ann Maxillofac Surg. 2014;4(2):171.

5. Machado MPS, Costa ST, Freire AR, Navega D, Cunha E, Daruge Júnior $E$, et al. Application and validation of Diagnose Sexuelle Probabiliste V2 tool in a miscegenated population. Forensic Sci Int. 2018;290:351-e1.

6. Phillips VM, Smuts NA. Facial reconstruction: utilization of computerized tomography to measure facial tissue thickness in a mixed racial population. Forensic Sci Int. 1996;83(1):51-59.

7. Arnett GW, Bergman RT. Facial keys to orthodontic diagnosis and treatment planning--Part II. Am J Orthod Dentofacial Orthop. 1993;103(5):395-411. https://dx.doi.org/10.1016/ s0889-5406(05)81791-3

8. Arnett GW, Bergman RT. Arnett GW, Bergman RT. Facial keys to orthodontic diagnosis and treatment planning. Part I. Am J Orthod Dentofacial Orthop. 1993 Apr;103(4):299-312. https://dx.doi.org/10.1016/0889-5406(93)70010-L

9. Magro-Filho O, Magro-Érnica N, Queiroz TP, Aranega AM, Garcia Jr IR. Comparative study of 2 software programs for predicting profile changes in Class III patients having doublejaw orthognathic surgery. Am J Orthod Dentofac Orthop. 2010;137(4):452-e1.

10. Lu C-H, Ko EW-C, Huang C-S. The accuracy of video imaging prediction in soft tissue outcome after bimaxillary orthognathic surgery. J Oral Maxillofac Surg. 2003;61(3):333-342.

11. Pektas ZÖ, Kircelli BH, Cilasun Ü, Uckan S. The accuracy of computer assisted surgical planning in soft tissue prediction following orthognathic surgery. Int J Med Robot Comput Assist Surg. 2007;3(1):64-71.

12. Chatzistavrou OKE. Factors Influencing the Accuracy of Cephalometric Prediction of Soft Tissue Profile Changes Following Orthognathic Surgery. 2012;11(1):82-90. https:// dx.doi.org/10.1007/s12663-011-0253-6

13. Resnick CM, Dang RR, Glick SJ, Padwa BL. Accuracy of threedimensional soft tissue prediction for Le Fort I osteotomy using Dolphin 3D software: a pilot study. Int J Oral Maxillofac Surg. 2017;46(3):289-295.

Received on: 20/5/2020

Approved on: 31/8/2020 